\title{
STRUKTUR KOMUNITAS KARANG DAN BIOTA ASOSIASI PADA KAWASAN TERUMBU KARANG DI PERAIRAN DESA MINANGA KECAMATAN MALALAYANG II DAN DESA MOKUPA KECAMATAN TOMBARIRI.
}

\section{(Coral Structure Community and Its Association Organism In Coral Reef at Minanga Village of Malalayang II and Mokupa Village of} Tombariri District Waters).

\author{
Jeremias R. Tuhumena ${ }^{1 *}$, Janny D. Kusen ${ }^{1}$, Carolus P. Paruntu ${ }^{1}$ \\ ${ }^{1}$ Program Studi IImu Kelautan, Fakultas Perikanan dan IImu Kelautan, Universitas Sam \\ Ratulangi, Manado \\ *e-mail: jere_tuhumena@yahoo.com
}

\begin{abstract}
Main purpose of this study were to know the community structure of coral and its associate organism as well as coral cover percentage. Data of coral cover percentage had been gathered by using LIT (Line Intercept Transect), whereas a quadrant had been used for associate organism. The study sites were at two locations, Minanga Village of Malalayang II District and Mokupa Village of Tombariri District waters. The result shown that coral cover percentage at two locations were very low. The diversity of marine organism in Minanga Village and Mokupa Village have the moderate diversity. Similarity of Ascidiacea and Algae organism communities were equal whereas Sponge, Echinoderm, Mollusc and Fish were unequal. Frequency of Mollusc and Crustacean have been shown as highest value, but Algae was the lowest value. Density of Ascidiacea, Sponge and mollusc organism have been shown highest value, whereas Echinoderm, Crustacean and Algae shown the lowest value at Minanga Village whereas at Mokupa Village Mollusc organism have been shown the highest density, while the Ascidiacea, Sponge, Algae and Polichaetes have the lowest value.
\end{abstract}

Keywords : Coral reef, Associations organism, Structure communities.

Tujuan studi yaitu untuk mengetahui struktur komunitas biota karang dan biota asosiasi di kawasan terumbu karang. Data tutupan karang diperoleh dengan menggunakan metode LIT (Line Intercept Transect) sedangkan untuk biota asosiasi diperoleh dengan menggunakan kuadran. Penelitian dilakukan pada dua lokasi yaitu di Desa Minanga Kecamatan Malalayang II dan Desa Mokupa Kecamatan Tombariri Provinsi Sulawesi Utara. Hasil yang diperoleh pada dua lokasi menunjukkan persentase tutupan karang yang sangat rendah. Biota pada Desa Minanga dan Desa Mokupa memiliki keanekaragaman sedang. Untuk kesamaan komunitas Ascidian dan Alga ditemukan sama, sedangkan Spons, Ekinodermata, Moluska serta Ikan berbeda pada kedua lokasi. Nilai Frekuensi biota pada Desa Minanga memiliki nilai tertinggi yaitu Ascidian yang terendah yaitu Krustasea dan Alga sedangkan nilai frekuensi pada Desa Mokupa memiliki nilai tertinggi yaitu Ascidian dan yang terendah yaitu Polikaeta dan Alga. Kepadatan Ascidian, Spons dan Moluska memiliki nilai tertinggi, sedangkan nilai terendah yaitu Ekinodermata, Krustasea dan Alga di Desa Minanga, sedangkan kepadatan Moluska memiliki nilai tertinggi sedangkan Ascidian, Spons, Alga dan Polikaeta memiliki nilai terendah di Desa Mokupa.

Kata Kunci : Terumbu karang, Organisme asosiasi, struktur komunitas. 


\section{PENDAHULUAN}

Terumbu karang adalah stukrur bawah air yang tersusun dari endapan kalsium karbonat $\left(\mathrm{CaCO}_{3}\right)$, yang dihasilkan oleh fauna karang yang pada umumnya dijumpai di perairan tropis (Razak dan Simatupang, 2005). Menurut Veron (1986), terumbu karang masuk dalam filum Cnidaria, kelas Anthozoa, ordo Scleractinia dan memiliki 15 famili. Adapula faktor-faktor fisika dan ekologi yang menjadi pembatas kehidupan terumbu karang yaitu suhu, salinitas, cahaya, sedimentasi, gelombang dan kedalaman. Faktor ekologi yaitu persaingan, pemangsaan dan grazing (Nybakken, 1988). Di daerah terumbu karang hidup organisme yang berasosiasi yaitu Alga, Krustasea, Moluska, Ekinodermata dan Ikan (Nontii, 2002). Menurut Romimohtarto dan Juwana (2007), terumbu karang merupakan ekosistem yang subur dan kaya akan makanan. Struktur fisiknya yang rumit, bercabang-cabang, berguagua dan berlorong-lorong membuat ekosistem ini habitatnya sangat menarik bagi banyak jenis biota laut baik flora maupun fauna. Struktur komunitas karang dan biota asosiasi pada kawasan terumbu karang di perairan Desa Minanga dan Desa Mokupa belum pernah diteliti. Tujuan penelitian ini untuk mendeskripsikan struktur komunitas fauna karang dan biota asosiasi melalui analisis bentuk kepadatan dan kepadatan relatif, frekuensi dan frekuensi relatif, persentase tutupan karang, kesamaan komunitas dan keanekaragaman.

\section{METODE PENELITIAN}

\section{a. Lokasi dan Waktu Penelitian}

Penelitian dilakukan di Desa Minanga Kecamatan Malalayang II dan Desa Mokupa Kecamatan Tombariri Provinsi Sulawesi Utara. Penelitian ini dilakukan selama 6 bulan, mulai bulan februari - juli tahun 2013.

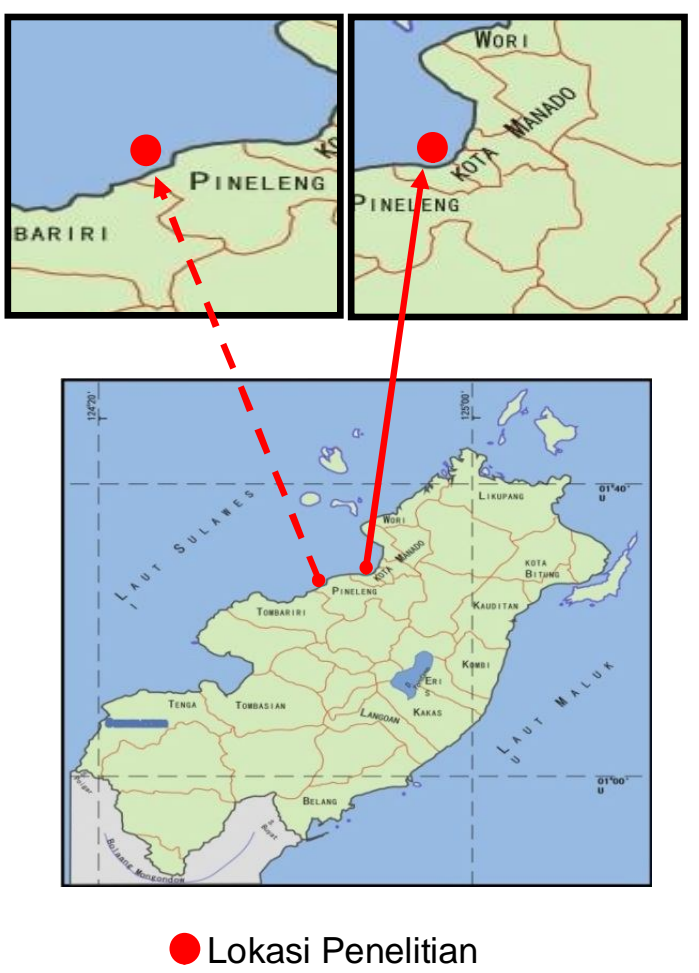

Gambar 1. Peta lokasi penelitian di Desa Minanga Kecamatan Malalayang II dan Desa Mokupa Kecamatan Tombariri (Sumber : Diinsert dari peta LPI 2417-05 BAKOSURTANAL 1995). Keterangan :

$\rightarrow \quad$ Desa Minanga
$\rightarrow \quad$ Desa Mokupa

\section{b. Prosedur Kerja}

Pengambilan data untuk tutupan terumbu karang menggunakan LIT yaitu mengukur tutupan karang yang dilewati atau bersinggungan dengan meteran, setelah itu melihat ke kiri dan ke kanan dalam radius $2 \mathrm{~m}$ untuk melihat jenisjenis ikan yang ada. Untuk pengambilan data biota asosiasi menggunakan kuadran (1x1 meter) yang diletakkan sebanyak 5 buah pada garis transek sepanjang 25 meter. Kemudian melihat biota dalam kuadran, sedangkan untuk sampel Moluska diambil dan diidentifikasi di Laboratorium Biologi Kelautan. 


\section{c. Analisa Data}

\section{Kepadatan Biota Karang}

Kepadatan spesies biota karang dianalisis dengan menggunakan rumus kepadatan (Odum 1994) :

Jumlah individu spesies

Kepadatan spesies $=$

Luas wilayah contoh $\left(\mathrm{m}^{2}\right)$

Kepadatan spesies $\mathrm{A}$

Kepadatan Relatif(\%) $=\longrightarrow \times 100$

Kepadatan spesies total

\section{Frekuensi Jenis Biota Karang}

\section{Frekuensi jenis biota karang dan fauna karang dianalisis dengan menggunakan formula menurut Bengen (2000):}

Dimana :

$$
\mathrm{Fi}=\mathrm{Pi} / \sum \mathrm{P}
$$

$\mathrm{Fi}:$ Frekuensi Jenis

$\mathrm{Pi}$ :Jumlah plot yang ditemukan jenis $\mathrm{i}$

$\Sigma \mathrm{P}$ : Jumlah semua plot

$$
\mathrm{Rfi}=\mathrm{Fi} / \Sigma \mathrm{F} \times 100
$$

Dimana :

$$
\begin{array}{ll}
\mathrm{RFi} & =\text { Frekuensi relatif } \\
\mathrm{Fi} & =\text { Frekuensi jenis } \mathrm{i} \\
\Sigma \mathrm{F} & =\text { Frekuensi semua jenis }
\end{array}
$$

\section{Persentase Tutupan Terumbu Karang} (\% cover)

Nilai persentase penutupan terumbu karang diperoleh dari hasil pengukuran life form karang dengan menggunakan formula (Gomez dan Yap 1988) :

$$
L(\%)=\frac{L i}{N} \times 100
$$

Dimana :

$$
\mathrm{L} \quad=\text { Persentase penutupan karang (\%) }
$$

$\mathrm{Li}=\underset{\text { koloni) jenis kategori ke-i }}{\text { Panjang lifeform }}$

$$
\mathrm{N}=\text { Panjang transek }(25 \mathrm{~m})
$$

\section{Kesamaan Komunitas}

Untuk mengetahui kesamaan komunitas biota karang dan fauna karang antar stasiun penelitian maka digunakan rumus koefisien kesamaan atau Indeks Sorensen (Odum 1994) sebagai berikut :

$$
\text { IS }(\%)=\frac{2 C}{A+B} \times 100
$$

Dimana,

IS = Indeks Sorensen

C = Jumlah spesies yang sama dan terdapat pada kedua stasiun

$A=$ Jumlah spesies dalam stasiun $A$

$\mathrm{B}$ = Jumlah spesies dalam stasiun $\mathrm{B}$

Dengan kriteria keputusan: dua stasiun tidak berbeda jika nilai IS > 50 .

\section{Indeks Keanekaragaman}

Indeks keanekaragaman spesies adalah ukuran kekayaan komunitas dilihat dari jumlah spesies dalam suatu kawasan, berikut jumlah individu dalam tiap spesies. Indeks keanekaragaman spesies dianalisis dengan menggunakan formula Shannon-Wiener dalam Ludwig dan Reynolds (1988).

$$
H^{\prime}=-\Sigma(n / N \text { In ni/N) }
$$

Dimana :

$\mathrm{H}^{\prime}$ : Indeks keanekaragaman spesies ni : Jumlah individu dalam spesies ke-i $\mathrm{N}$ : Jumlah total individu Keterangan :

$\mathrm{H}^{\prime}<1$ : Keanekaragaman rendah dan keadaan komunitas rendah $1<\mathrm{H}^{\prime}<3$ : Keanekaragaman sedang dan keadaan komunitas sedang $\mathrm{H}^{\prime}>3$ : Keanekaragaman tinggi dan keadaan komunitas tinggi. 


\section{HASIL DAN PEMBAHASAN}

\section{a. Kepadatan dan Kepadatan Relatif Biota}

Hasil perhitungan indeks kepadatan dan kepadatan relatif biota asosiasi pada Desa Minanga dan Desa Mokupa berkisar antara $0,01-3 \mathrm{ind} / \mathrm{m}^{2}$ dan nilai kepadatan relatif berkisar antara $0,72-14,3 \%$. Hal ini diduga akibat substrat dari jenis biota yang ada pada dua lokasi penelitian yang berbeda. Menurut Abrar dan Menuputty (2008) bahwa, kehadiran dan sebaran Ascidian berada pada daerah yang didominasi oleh substrat keras dan patahan karang. Spons berada pada daerah yang keras yaitu seperti di daerah terumbu karang (Hadi, 2010). Ekinodermata memiliki tempat hidup pada daerah terumbu karang karena terdapat banyak makanan. Xanthidae sp memiliki tempat hidup pada daerah yang berbatu dan celah-celah karang hidup dan mati (Edmonson, 1962). Spirobranchus gigantheus terdapat pada daerah yang asin dan tidak ada pada habitat yang lainnya (Pamungkas, 2011). Menurut Romimohtarto dan Juwana (2007), alga hijau terdapat terutama di mintakat litoral bagian atas, khususnya di bagian bawah dari mintakat pasut. Moluska yang lebih umum dikenal dengan keong laut yang biasa dijumpai pada di berbagai jenis lingkungan dan menyesuaikan dengan bentuk lingkungannya (Nonjti, 2002). Ikan karang pada umumnya dipengaruhi oleh oleh kondisi terumbu karang yang baik dan jaringan makanan yang cukup tinggi sehingga keanekaragaman ikan sangat tinggi.

\section{b. Frekuensi dan Frekuensi Relatif Biota Asosiasi}

Hasil perhitungan indeks frekuensi dan frekuensi relatif biota asosiasi pada Desa Minanga dan Desa Mokupa berkisar antara 0,2- 1,3 dan nilai kepadatan relatif berkisar antara 3,2 - 20\%. Hal ini diduga akibat substrat dan aktifitas dari manusia pada perairan. Menurut Abrar dan Manuputty (2008) bahwa, Ascidian umumnya berada pada daerah terumbu karang yang masih hidup maupun yang sudah mati. Spons pada perairan berada pada daerah yang memiliki substrat keras seperti di daerah terumbu karang (Hadi, 2010). Jenis Ekinodermata seperti bulu babi, bintang laut dan jenis yang lainnya mempunyai tempat hidup pada daerah terumbu karang dan celah-celah terumbu karang (Nontji, 2002). Alga hidup di dasar laut mulai dari zona pasang surut sampai sedalam sinar matahari dan hidup menempel pada dasar yang keras seperti terumbu karang (Nontji, 2002). Moluska hidup berada pada daerah yang didominasi oleh puing-puing terumbu, lembaran karang mati dan batu-batuan (Allen dan Steene, 1994).

\section{c. Persentase Tutupan Terumbu Karang}

Hasil dari persentase tutupan terumbu karang pada Desa Minanga berkisar antara 1,12-39,64\%. Hal ini diduga disebabkan oleh fauna pemangsa dan aktifitas manusia pada Desa Minanga. Menurut Kaleka (2004) bahwa, terumbu karang di Semenanjung Sulawesi Utara tak luput dari permasalahan yang sama. Fauna pemakan coral Acanthaster planci yang semakin meningkat, masuknya sampah/eutrofikasi dan tekanan akibat aktifitas manusia yang berlebihan.

Pada Desa Mokupa memiliki nilai persentase tutupan terumbu karang yang berkisar antara 0,4-67,4 \%. Hal ini diduga akibat aktifitas manusia dan salinitas. Menurut Dahuri, dkk. (2008) 
bahwa, kerusakan terumbu karang yang diakibatkan oleh manusia diantaranya ialah penambangan karang dengan atau tanpa menggunakan bahan peledak, pengurukan disekitar terumbu karang, parawisata dan lainnya. Menurut Romimohtarto dan Juwana (2007) bahwa, terumbu karang berkembang pada salinitas air tetap di atas $30-35$ PSU.

\section{d. Indeks Keanekaragaman Biota Asosiasi}

Nilai indeks keanekaragaman biota pada Desa Minanga berkisar antara 2,71 - 2,94 dan Desa Mokupa, berkisar antara 2,3-2,8. Hal ini diduga disebabkan oleh substrat, arus dan aktifitas manusia. Hal ini didukung oleh pernyataan dari Abrar dan Manuputty (2008) bahwa, keanekaragaman Ascidian akan banyak tumbuh pada substrat keras dan patahan terumbu karang yang ditumbuhi oleh Alga. Menurut Romimohtarto dan Juwana (2008) bahwa, sebaran dari Spons ini didukung oleh larva yang bergerak aktif atau oleh fauna muda yang terbawa arus sebelum Spons tersebut menempel. Biota Ekinodermata dapat tersebar di lingkungan yang disukainya karena dipengaruhi oleh substrat dan pakannya seperti Alga dan Lamun dan banyak dijumpai pada perairan dangkal dengan kedalaman 0-6 meter (Rachmawati, 2012). Penelitian yang dilakukan oleh Dauer and Conner (1980) di pantai Old Tampa, Florida, menyatakan jumlah dan biomassa Polikaeta mengalami peningkatan di daerah yang mengalami peningkatan nutrien dari limbah rumah tangga sebesar 4 kali dari Polikaeta yang berada pada lokasi yang tidak mengalami peningkatan nutrien.
Menurut Nybakken (1988) bahwa, keberadaan makro Alga sangat ditentukan oleh ketersediaan cahaya matahari. Umumnya makro Alga terdapat pada daerah intertidal atau subtidal sampai batas kedalaman 200 meter. Banyak Moluska dari Kelas Gastropoda yang ditemukan pada setiap stasiun di Banten diduga karena kemampuan adaptasinya yang tinggi baik dari substrat keras maupun lunak (Dibyowati, 2009). Menurut Najamuddin (2012) bahwa, komunitas Ikan karang ditemukan beragam pada daerah terumbu karang yang jauh dari pemukiman karena umumnya memiliki kondisi yang baik.

\section{e. Nilai Koefisien Kesamaan Komunitas Biota Asosiasi}

Nilai koefisien kesamaan komunitas pada lokasi penelitian memiliki nilai yang berbeda. Biota Ascidian pada dua lokasi sama yaitu Alga dan Ascidian. Hal ini diduga karena substrat dari biota tersebut yang cocok bagi biota-biota ini. Pernyataan ini didukung oleh pernyataan dari Abrar dan Manuputty (2008) bahwa, Ascidian akan banyak tumbuh pada substrat yang keras dan patahan terumbu karang yang ditumbuhi oleh Alga. Ditambahkan oleh Nontji (2002) bahwa, Alga yang dapat hidup di dasar laut banyak terdapat di sepanjang pantai mulai dari zona pasang-surut sampai sedalamnya sinar matahari dapat tembus. Sedangkan biota yang tidak sama antara dua lokasi penelitian yaitu Spons, Ekinodermata, Moluska dan Ikan. Hal ini diduga terjadi karena substat, fauna pemangsa dan aktifitas manusia. Menurut Hadi (2010) bahwa, fauna pemangsa Spons pada perairan air laut diantaranya yaitu dari jenis penyu sisik, 
bintang laut dan dari jenis Moluska yaitu Nudibranchia. Biota Ekinodermata mempunyai tempat hidup yaitu di daerah terumbu karang, karena terdapat banyak makanan, pada jenis bintang laut mengular merupakan individu yang hidup pada celah-celah karang, sedangkan bintang laut berduri umumnya hidup merusak sistem dari terumbu karang. Moluska yang banyak dijumpai pada berbagai jenis lingkungan dan bentuknya telah menyesuaikan dengan lingkungan tersebut (Nontji, 2002). Menurut Najamuddin dkk. (2012) bahwa, keberadaan ikan dipengaruhi oleh kondisi terumbu karang, dimana pada daerah terlindungi dan daerah terbuka biasanya terdapat terumbu karang yang mempunyai struktur morfologi yang berbeda.

\section{KESIMPULAN}

Kesimpulan yang dapat diambil dari hasil penelitian yang dilakukan yaitu

1. Kepadatan Biota asosiasi Ascidian, spons dan moluska di Desa Minanga tinggi, sedangkan ekinodermata, krustasea dan alga rendah. Sedangkan kepadatan biota asosiasi di Desa Mokupa tinggi yaitu moluska, sedangkan yang rendah yaitu Ascidian, spons, ekinodermata, alga dan polikaeta,

2. Frekuensi kehadiran Biota asosiasi di Desa Minanga memiliki nilai rata-rata yaitu 0,51 dan nilai frekuensi relatif yaitu 10,34\%. Frekuensi kehadiran Biota asosiasi di Desa Mokupa memiliki nilai 0,43 dan nilai frekuensi relatifnya yaitu $10,34 \%$,

3. Tutupan karang pada Desa Minanga sangat rendah dan pada Desa Mokupa memiliki tutupan terumbu karang yang rendah,
4. Indeks Kesamaan Komunitas jenis Ascidian dan alga di Desa Minanga dan Desa Mokupa yaitu sama, sedangkan kesamaan komunitas spons, ekinodermata, ikan dan moluska yaitu berbeda,

5. Nilai Indeks Keanekaragaman biota asosiasi dengan terumbu karang di Desa Minanga dan Desa Mokupa sedang.

\section{DAFTAR PUSTAKA}

Abrar, M., Manuputty, A. E. W., 2008. Inventarisasi dan Sebaran Biota Ascidian di Terumbu Karang Perairan Berau, Kalimantan Timur. Pusat penelitian Oseanografi, LIPI. 47-66 hal.

Allen, G. 1994. Marine Fishes Of South - East Asia . Published by Periplus Editions, 293 pp.

Bengen, D.G. 2000. Sinopsis Ekosistem dan Sumber Daya Alam Pesisir. Pusat Kajian Sumberdaya Pesisir dan Lautan - Institut Pertanian Bogor. Bogor, Indonesia.

Cappenberg, H. A. W., Aziz, A and Aswandy, I. 2006. Komunitas Moluska di Perairan Teluk Gilimanuk, Bali Barat. Oseanologi dan Limnologi di Indonesia. No. 40:53-64.

Dahuri, H. R., Rais, J., Ginting, S. P., Sitepu, M. J., 2008. Pengelolaan Sumber Daya Wiayah Pesisir dan Lautan Secara Terpadu. Penerbit PT. Pradnya Paramita, Jakarta. Ed. Rev.,cet. ke-4. Hal. $197-201$

Dibyowati, L. 2009. Keanekaragaman Moluska ( Bivalvia dan Gastropoda) di Sepanjang Pantai Carita, Pandeglang, Banten. Fak. Matematikan dan IImu Pengatahuan Alam, Jurnal IPB. Bogor, Indonesia.

Gomez, E. D. and Yap, H. T. 1988. Monitoring Reef Condition in: Kenchington, R. A.and B. E. T. Hudson (ed.): Coral Reef Management Hand Book. 
UNESCO Regional Office for Science and Technology for South East Asia. Jakarta.

Hadi, T. A. 2010. Biologi dan Ekologi Spons. Oseana. Jurnal. Volume XXXV, Nomor 1. 33-48 hal.

Kaleka, D. M. W., 2004. Transplantasi Karang Batu Marga Acropora Pada Substrat Buatan di Perairan Tablolong Kabupaten Kupang. Makalah Falsafah Sains (PPS 702), Program S3 IPB. 8 hal.

Ludwig, J. A and Reynolds, J.F. 1988. Statistical Ecology.A Primer on Methods and Computing Jhon Wiley \& Sons, Inc. Toronto. Canada.

Najamudin, Ishak, S., dan Ahmad, A. 2012. Keragaman Ikan Karang di Perairan Pulau Makian Provinsi Maluku Utara. Jurnal. Depik, 1(2): 114-120.

Nontji A., 2002. Laut Nusantara. Djambatan, Jakarta. 367 hal.

Nybakken, J. W. 1988. Biologi Laut: Suatu Pendekatan Ekologis. Penerbit. PT. Gramedia Pustaka Utama, Jakarta, 325-363.

Odum, E.P. 1994. Dasar-Dasar Ekologi. Terjemahan Samingan. $T$ dan Srigando, B. Gajah Mada Press, Yogyakarta. 230 hal.

Pamungkas, J. 2011. Cacing Laut dan Keindahannya. Oseana, Jurnal. Volume XXXVI. Nomor 2. 21-29 hal.

Razak, T, B dan Simatupang, K. L. M. A., 2005. Buku Panduan Pelestarian Terumbu Karang; Selamatkan Terumbu Karang Indonesia. Yayasan Terangi, Jakarta, 113 hal.

Rachmawati, E, R. 2012. Pola Sebaran dan Keanekaragaman Echinodermata di Perairan Leuweung Sancang. Universitas Pendidikan Indonesia, Indonesia.
Romimohtarto, K, Juwana, S. 2007. Biologi Laut : IImu Pengetahuan Tentang Biota Laut. Penerbit Djambatan, Jakarta. Ed. Rev.,cet. Ke-3. Hal. 321 - 332.

Veron, J. E. N., 1986, Corals of Australia and the Indo-Pacific. August Robertson. Publisher, 644 pp. 